\title{
Surveys on the Consumption of Attiéké (Traditional and a Commercial, Garba) in Côte d'Ivoire
}

\author{
Justine Bomo Assanvo ${ }^{1}$, Georges N'zi Agbo ${ }^{1} \&$ Zakaria Farah $^{2}$ \\ ${ }^{1}$ Laboratory of Biochemistry and Food Science, Félix Houphouët Boigny University, Abidjan, Côte d'Ivoire \\ ${ }^{2}$ Institute of Food Science and Nutrition/Laboratory of Food Chemistry and Technology, Swiss Federal Institute \\ of Technology (ETH), Zurich, Switzerland \\ Correspondence: Justine Bomo Assanvo, Laboratory of Biochemistry and Food Science, UFR Biosciences, Félix \\ Houphouët Boigny University, Abidjan, 22 BP 582 Abidjan 22, Côte d'Ivoire. Tel: 00 225-0778-6755. E-mail: \\ justinebomo2015@gmail.com
}

Received: May 2, 2019

doi:10.5539/jfr.v8n4p23

\author{
Accepted: May 17, 2019 Online Published: May 31, 2019 \\ URL: https://doi.org/10.5539/jfr.v8n4p23
}

\begin{abstract}
Traditional attiéké and commercial attiéké Garba are fermented cassava semolina, steamed and prized by people living in the big cities of Côte d'Ivoire and elsewhere. Attiéké Garba is a derivative of the traditional attiéké resulting from intended manufacturing defects. A consumption survey was therefore conducted in Abidjan (big city) and two departments, Dabou and Jacqueville, major production areas of attiéké and Garba, to assess the importance and determinants of consumption of 4 types of attiéké (Adjoukrou, Ebrié, Alladjan and Garba), consumer preferences and to identify the descriptors of quality that motivate the consumption of these food products. Surveys showed that $99 \%$ of respondents consume regularly 1 to 2 times attiéké (traditional or commercial) per day. The consumption of attiéké is related to the organoleptic properties of the different types of attiéké mainly taste $(65 \%)$, brightness (35\%), absence of fibers (33\%), color (22\%) and odor (21\%). The consumption of attiéké Garba is linked to its character of cheap food. Despite the preference of attiéké Adjoukrou (38\%) and Ebrie (29\%) for their better quality and popularity, the consumption of Garba (10\%) is growing. Income, nationality or ethnicity, sex, socio-professional status and educational level have a major influence on the choice of a type of attiéké. The share of consumption of traditional attiéké and commercial attiéké Garba for middle-income consumers (70,000 CFA F $<\mathrm{r} \leq 200,000$ CFA F) and high income ( $r>200,000$ CFA F) is respectively $23.44 \%$ and $7.33 \%$ while it is $21.03 \%$ and $41.35 \%$ respectively for low-income consumers ( $\mathrm{r}<70,000 \mathrm{CFA}$ F).
\end{abstract}

Keywords: cassava, traditional attiéké, attiéké Garba, consumption, descriptors of quality

\section{Introduction}

In Côte d'Ivoire, cassava roots are preferentially used in the manufacture of several types of attiéké. According to Assanvo et al. (2017), the consumption of attiéké in Côte d'Ivoire, is estimated today at about 1300000 tonnes / year. It continues to grow in view of the growing importance of commercial attiéké Garba in the diet of low-income working populations.

Attiéké is a food produced from a fermented cassava paste, in the form of steamed granules. Originally, attiéké was consumed exclusively in a restricted ethno-cultural setting in the Ivorian lagoon complex where the Adjoukrou, Ebrié, Alladjan, Avikam, Aizi and Neo ethnic groups live. Of these ethnic groups, Adjoukrou, Ebrié and Alladan remain the largest producers and consumers (Kouadio, Kouakou, Angbo, \& Mosso, 1991). Gradually, attiéké has acquired a market value because it constitutes an important source of income for producers. In addition, today this product has spilled over into its home environment and is being consumed all over the country due to its "ready-to-eat" presentation (Assanvo, Agbo, Behi, Coulin, \& Farah, 2006). This product is exporting to border countries, some countries in Africa, Europe and the United States through an informal network. On the other hand, other foods with similarity to attiéké appear (Sotomey, Ategbo, Mitchikpe, Gutierrez, $\&$ Nago, 2001).

According to Assanvo (2008), attiéké Garba differs from traditional attiéké on several steps of production: reduction of the fermentation time of cassava paste, elimination of drying, granulation and winnowing stages. 
These steps ensure the attiéké a better quality. The absence of well-made grains, sensation of grain in mouth and the accentuated color due to the large quantity of oil added during the manufacture of attiéké Garba gave this product the name of speed attiéké. In addition, if traditional attiéké is often eaten as an accompaniment to traditional sauces or the combination of fried or shredded fish and vegetables (onions, tomatoes, chillies) at home or during ceremonies, attiéké Garba is sold for street consumption only, and eaten exclusively with tuna fish. However, despite its poor nutritional and sanitary quality, Garba is being consumed more and more especially in big cities like Abidjan. This phenomenon leads to a substitution of the traditional attiéké by Garba in some cities of Côte d'Ivoire.

Previous studies have focused on production, economic analysis of the traditional cassava processing industry in attiéké in the Abidjan region, conservation methods, biochemical, microbiological and fermentative aspects (N'zore, 1985; Kouadio et al., 1991; Diop, 1992; Aboua, 1998; Fortin, Desmarais, Assovie, \& Diallo, 1998; Heuberger, 2005; Coulin, Farah, Assanvo, Spillmann, \& Puhan, 2006; Kastner et al., 2006; Kastner et al., 2007; Gnagne, Koffi, Assanvo, \& Soro, 2016; Assanvo et al., 2017). Despite the importance of this extensive work on attiéké, few focused on the consumption determinants, reasons and preferences of attiéké and other starchy foods on the Ivorian market. The present study aims at investigating the consumption determinants of traditional attiéké and Garba. The goal is the valorization of the traditional Ivorian attiéké. Specifically, the study compared three traditional attiéké and the Garba through consumer surveys to identify similarities and differences between these four types of attiéké. The appreciation of attiéké consumers was defined by the quality descriptors of the traditional finished product, their importance and their level of consumption and preference for populations compared to other foods marketed in Côte d'Ivoire.

\section{Method}

\subsection{The Different Types of Traditional Attiéke Used for Surveys}

Four (4) main types of attiéké systematically corresponding to three traditional attiéké (Ebrié, Adjoukrou and Alladjan) and the commercial attiéké Garba were the subject of a survey on their consumption (table 1). Ebrié, Adjoukrou and Alladjan are ethnic groups of the Southern Côte d'Ivoire.

Table 1. Sample size used for the attiéké consumption survey

\begin{tabular}{lllll}
\hline $\begin{array}{l}\text { City/ } \\
\text { Department }\end{array}$ & $\begin{array}{l}\text { Township/ } \\
\text { village }\end{array}$ & $\begin{array}{l}\text { Number of } \\
\text { neighborhoods investigated }\end{array}$ & $\begin{array}{l}\text { Number of } \\
\text { households surveyed }\end{array}$ & $\begin{array}{l}\text { Type of } \\
\text { attiéké consumed }\end{array}$ \\
\hline Abidjan & Yopougon & 7 & 120 & Ebrié, Adjoukrou \\
& Cocody & 8 & 160 & Alladjan, Garba \\
& Koumassi & 11 & 101 & \\
Dabou & Nouvel Ousrou & 3 & 30 & \\
& Bouboury & 3 & 30 & \\
& Orbaff & 3 & 30 & \\
Jacqueville & Grand-Jack & 3 & 30 & \\
& Ahua & 3 & 30 & \\
& Sassako Begniny & 3 & 30 & \\
\hline
\end{tabular}

\subsection{Study Area}

The General Census of Population and Housing (GCPH) of 1998 and 2014 was used as the basis of the survey (Anonymous, 1998, 2014). The RGPH has revealed that the city of Abidjan (economic capital of Côte d'Ivoire) is an area of ethnic diversity. All major cultural groups of Côte d'Ivoire are represented, as well as populations from neighboring countries (Mali, Burkina Faso, Ghana, Nigeria, Niger, Benin, Togo, Guinea, etc ...). This wide representation allowed a large restriction of the consumption survey to the city of Abidjan, particularly the communes of Yopougon, Cocody, Koumassi. These 3 communes comprise $60 \%$ of the population of Abidjan according to the GCPH 2014. For completing the data, consumers from 3 villages per department of Dabou Jacqueville were investigated (Figure 1, Table 1). The city of Abidjan (2,877,948 in 1998, 4,395,243 in 2014) and the departments of Dabou (120,304 in 1998, 148,874 in 2014) and Jacqueville (52,871 inhabitants in 1998, 56,308 in 2014), represent large areas of production and regular consumption of traditional attiéké, Abidjan being the area of mass production of attiéké Garba (Figure 1).

\subsection{Survey Plan}

The survey methods of Dussaix and Grosbras (1996) and Tillé (2001) were adopted for the present study. The 
sampling method applied in this consumption survey on attiéké is the three-stage cluster survey, the primary level being the communes or villages surveyed, at the secondary level the neighborhoods and the tertiary level, the households surveyed (Table 1).

In each commune or village, neighborhoods and households were randomly selected. The interlocutors were identified within each household according to their availability to answer the questions. A household has an average of 6 persons. The overall sample size was 561 households interviewed in 44 investigated neighborhoods (Table 1). Surveys were conducted in families using semi-structured interviews. The family represents the sampling unit.

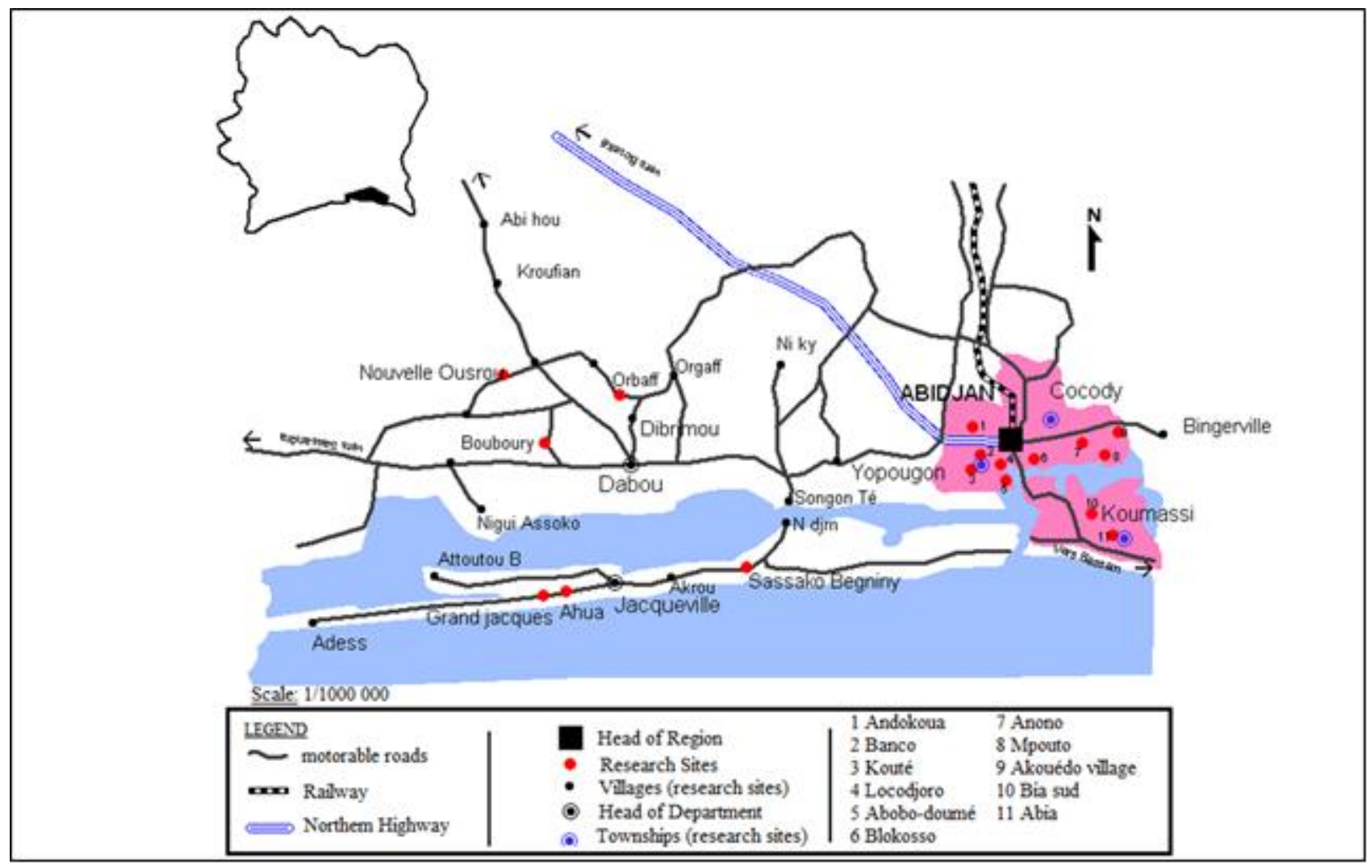

Figure 1. Map of study site presenting the attiéké consumption areas included in the survey

Scale: 1/1000.000; source: Map BNETD / CCT modified

\subsection{Collection Support (Survey)}

A pre-survey was conducted in the village of Adiopodoumé in April 1999 to collect information that was used to prepare the survey questionnaire. This village is located $17 \mathrm{~km}$ from Adjamé (Abidjan commune). The survey was repeated in 2006 and then in 2017 for a data update and conducted following production survey (Assanvo, 2008). The choice of the three communes and six villages (primary units) included the density of the populations, the average income level of the resident populations, the importance of the outlets and the geographical position of each municipality. The survey dwelt on the factors of choice of an attiéké type. Thus, socio-demographic and organoleptic characteristics were considered. A standard questionnaire tested beforehand, served as a support for the survey.

The questionnaire consisted of the following three sections:

Section 1: Identification of the respondent. This section collects sociodemographic information on men and women surveyed;

Section 2: Determinants, level, importance, reasons for consumption of types of attiéké and the factors influencing their preference;

Section 3: Importance of descriptors quality according consumers. 


\subsection{Statistic Analysis}

The results were recorded in a database. A frequency calculation was carried out. The preference of one type of attiéké was classified in three reasons according to the definition of consumers. The descriptive statistics of survey data was performed using the software SAS version 8.2.

The level of income ( $r$ ) expressed in CFA franc was classified into 3 categories: low income ( $r<70,000$ CFA francs), average income (70,000 CFA francs $<r<200,000$ CFA francs) and high income ( $r \geqslant 200,000$ CFA francs) on the basis of the salaries of civil servants in Cote d'Ivoire.

Differences in consumption between ethnicity or nationality, gender, age, income level, socio-occupational status, level of education, townships or villages and preferences were tested.

\section{Results}

\subsection{Consumption and Preference of Attiéké Types}

\subsubsection{Attiéké Consumption Level}

A total of 561 households were surveyed, of which $62 \%$ were women and $38 \%$ were men. The age of consumers was 5-80 years and divided into 8 age groups: 5-14 years (10.88\%), 15-19 (17.29\%), 20-30 (18.18\%), 31-40 (17.47\%), 41-50 (11.76\%), 51-60 (11.23\%), 61-70 (8.73\%) and 71-80 (4.46\%). The surveyed consumer population includes 4 levels of education: Illiterate $(13.37 \%)$, Primary $(40.99 \%)$, Secondary $(32.27 \%)$ and Superior (13.37\%).

Apart from other dishes (rice, foutou, placali, etc.), almost all the households surveyed (99\%) consumed at least one time attiéké per day. With regard to ethnicity or nationality, Ebrié, Alladjan and Adjoukrou consumed attiéké one (1) to two (2) times per day. The other ethnic groups (Avikam, Aizi, Attié, Abouré, Agni, Baoulé, Senoufo, Abey and other ethnicities or nationalities, Table 2) consumed attiéké on average only once a day or not at all.

For nationalities, $75 \%$ of foreign populations living in Côte d'Ivoire (Table 2), consumed Garba more than traditional attiéké. For natives, $40 \%$ prefer to eat Garba.

At income level, consumers with incomes 100,000-200,000 CFA francs/month consume attiéké on average only one (1) time per day. Persons with income $\geq 200,000$ CFA francs consume once or not at all per day. On the other hand, those with incomes $<70,000$ CFA francs, consume an average of two (2) times per day. It appears that the lower the income level, the higher the consumption (Table 3).

The analysis of socio-professional situation of interviewed persons (male or female) revealed the better the socio-professional situation, the lower the consumption of traditional attiéké and attiéké Garba (table 4). Similarly, the higher the level of education, the lower the consumption of attiéké but especially that of Garba highly decreases. In fact, households whose heads of families have a higher level of education consume an average of 1 time day per day or not at all traditional attiéké or Garba. On the other hand, the illiterate households or with primary and secondary education levels consume mostly daily at least 1 time traditional attiéké or commercial attiéké, Garba.

The results of the survey revealed a higher consumption of traditional attiéké for women compared to men (twice a day for women and once a day for men). Consumption of attiéké Garba was higher in men than in women (twice a day for men and once a day for women).

The primary reason for consumption of attiéké was eating habit, staple food or preferred food. The second reason was satiety, good taste and nourishing character. The third reason was the economic nature of attiéké, low cost, availability, well-made appearance, durability and ready-to-eat character of attiéké.

The communes surveyed in Abidjan or the villages in Dabou and Jacqueville were classified by percentage of consumption reasons. Thus in Abidjan, for reason 1, Koumassi (41\%) and Yopougon (35\%) had the highest percentages. For Cocody, 24\% was recorded. For reason 2, Yopougon came first with $39 \%$ followed by Koumassi (35\%) and Cocody (26\%). However, for reason 3, Cocody has the highest percentage of consumption (46\%), followed by Koumassi (40\%) and Yopougon (14\%). In Dabou (65\%) and Jacqueville (70\%), reason 1 was predominant in all the villages surveyed, followed by reason 2 which represented $25 \%$ in Dabou and $20 \%$ in Jacqueville.

\subsubsection{Preference Level of Attiéké Types}

The ranking obtained with the data collected indicates that $38 \%$ of the households surveyed prefer to consume attiéké Adjoukrou, 29\% attiéké Ebrié, 23\% attiéké Alladjan and 10\% attiéké Garba (figure 2).

The assessment of the different types of attiéké (Ebrié, Adjoukrou, Alladjan and Garba) by ethnicity or 
nationality, excluding the traditional producing ethnic groups (Ebrié, Alladjan and Adjoukrou), showed that the other ethnicities or nationalities prefer consuming the attiéké Adjoukrou (53\%) followed by attiéké Ebrié (29\%). However, for Attié ethnic group, the preference for the three types of attiéké, Ebrié, Adjoukrou, Alladjan was equal $(33.33 \%)$. Whether Baoulé have a substantially equal preference for attiéké Ebrié $(50 \%)$ and attiéké Adjoukrou (40\%), the Abouré do not differentiate attiéké Adjoukrou (50\%) and attiéké Alladjan (50\%). This ethnic group had no preference for attiéké Ebrié and others.

Table 2. Number of times per day of average consumption of studied attiéké (Adjoukrou, Ebrié, Alladjan and Garba) by ethnicity or nationality

\begin{tabular}{|c|c|c|c|c|}
\hline Nationality & Ethnic group & $\begin{array}{l}\text { Number of } \\
\text { households }(n=561)\end{array}$ & Percentage $(\%)$ & $\begin{array}{l}\text { Number of times per day average } \\
\text { consumption of attiéké (traditional / Garba) }\end{array}$ \\
\hline \multirow{30}{*}{ Ivorian } & Ebrié & 90 & 16.04 & 2 \\
\hline & Adjoukrou & 50 & 8.91 & 2 \\
\hline & Alladjan & 50 & 8.91 & 2 \\
\hline & Aizi & 10 & 1.78 & 1 \\
\hline & Avikam & 10 & 1.78 & 1 \\
\hline & Néo & 5 & 0.89 & 1 \\
\hline & Abidji & 5 & 0.89 & 1 \\
\hline & Attié & 10 & 1.78 & 1 \\
\hline & Abey & 10 & 1.60 & 1 \\
\hline & Abourey & 12 & 2.14 & 1 \\
\hline & Appolo or N'zima & 15 & 2.67 & 1 \\
\hline & Baoulé & 36 & 6.42 & 1 \\
\hline & Agni & 14 & 2.5 & 1 \\
\hline & Abron & 4 & 0.71 & 1 \\
\hline & Dioula & 24 & 4.28 & 1 \\
\hline & Koyaka & 6 & 1.1 & 1 \\
\hline & Mahouka & 6 & 1.1 & 1 \\
\hline & Senoufo & 10 & 1.78 & 1 \\
\hline & Tangbanan & 7 & 1.25 & 1 \\
\hline & Yacouba & 9 & 1.60 & 1 \\
\hline & Gouro & 13 & 2.32 & 1 \\
\hline & Gagou & 5 & 0.89 & 1 \\
\hline & Guéré & 6 & 1.1 & 1 \\
\hline & Wobé & 7 & 1.25 & 1 \\
\hline & Bété & 18 & 3.21 & 1 \\
\hline & Dida & 10 & 1.78 & 1 \\
\hline & Kroumen & 8 & 1.43 & 1 \\
\hline & Toura & 4 & 0.71 & 1 \\
\hline & Koulango & 6 & 1.1 & 1 \\
\hline & Lobi & 6 & 1.1 & 1 \\
\hline Total Ivorian & & 466 & $83.07 \%$ & \\
\hline Burkinabe & & 10 & 1.78 & 1 \\
\hline Malian & & 9 & 1.60 & 1 \\
\hline Guinean & & 8 & 1.43 & 1 \\
\hline Togolese & & 10 & 1.78 & 1 \\
\hline Beninese & & 9 & 1.60 & 1 \\
\hline Nigerian & & 7 & 1.25 & 1 \\
\hline Ghanaian & & 10 & 1.78 & 1 \\
\hline Nigerian & & 10 & 1.78 & 1 \\
\hline Senegalese & & 9 & 1.60 & 1 \\
\hline Cameroonians & & 8 & 1.43 & 1 \\
\hline Congolese & & 5 & 0.89 & 1 \\
\hline Total foreign & & 95 & $16.93 \%$ & \\
\hline
\end{tabular}


Table 3. Daily consumption of traditional attiéké and attiéké Garba by income level

\begin{tabular}{llll}
\hline Income level of the households surveyed, $\mathrm{n}=561$ & Number of households & Percentage $(\%)$ & Number of times per day \\
\hline 0-10,000 CFA F (0-17.02 dollar US) & 65 & 11.58 & 2 \\
10,000-20,000 CFA F (17.02-34.04 dollar US) & 86 & 15.33 & 2 \\
20,000 -50,000 CFA F (34.04-85.09 dollar US) & 137 & 24.42 & 2 \\
$70,000-100,000$ CFA F (119.13-170.19 dollar US) & 123 & 21.95 & 1 \\
150,000-200,000 CFA F (255.28-340.38 dollar US)- & 80 & 14.25 & 1 \\
$\geq 200,000$ CFA F ( $\geq 340.38$ dollar US) & 70 & 12.47 & 1 \\
\hline
\end{tabular}

Table 4. Daily consumption status of traditional attiéké and commercial attiéké Garba by socio-professional

\begin{tabular}{llll}
\hline $\begin{array}{l}\text { Socio-professional situation of } \\
\text { household managers (male / female) }\end{array}$ & $\begin{array}{l}\text { Number of } \\
\text { households }\end{array}$ & Percentage (\%) & $\begin{array}{l}\text { Average number of } \\
\text { times per day }\end{array}$ \\
\hline Frame & 69 & 12.30 & 0 à 1 \\
Administrative employee & 136 & 24.24 & 1 \\
Liberal employee & 104 & 18.54 & 1 \\
Worker & 152 & 27.09 & 2 \\
Unemployed & 100 & 17.82 & 2 \\
\hline
\end{tabular}

According to municipalities, the inhabitants of Yopougon consumed attiéké Ebrié (40\%) and attiéké Adjoukrou (34\%) more than attiéké Alladjan (26\%). However, in Cocody, people consumed as much attiéké Adjoukrou $(16 \%)$ as attiéké Ebrié (15\%). The commune of Koumassi had a clear preference for attiéké Adjoukrou (61\%) whereas the preference of attiéké Ebrié and Alladjan was 16\%. The percentage of preference attributed to attiéké Garba was not very high (7\%) but its preference was better perceived than in Yopougon and Cocody. With regard to the villages of Dabou and Jacqueville, almost all the inhabitants preferred consuming attiéké locally produced. Sometimes, the foreign populations of these villages consumed other types of attiéké when they are outside the producing villages.

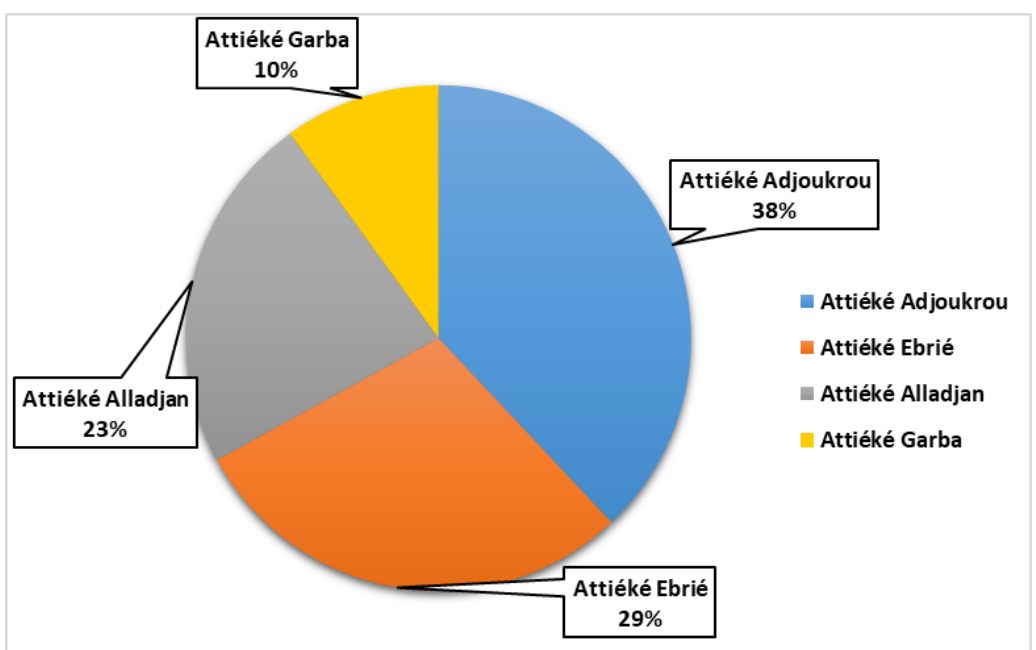

Figure 2. Percentage preference of different types of attiéké (Ebrié, Adjoukrou, Alladjan, and Garba) by the households surveyed

Almost all consumers (99.62\%) rejected the acidity of attiéké. The sweetness is the most sought (59.31\%), followed by the neutral character $(37.26 \%)$. The salty character does not matter because salt can be added if needed.

Most households (58\%) preferred the cream color of attiéké while 35\% preferred the yellow color. Only a few (7\%) and especially the Ebrié preferred it off-white. As a general rule, the indigestible character of attiéké is mostly not accepted by usual consumers.

Two important criteria of preference for producers and sellers were the conservation mode and duration of 
attiéké. Generally kept in bags or in baskets covered with banana leaves, attiéké can lose its quality if not well cooked and / or preserved.

Attiéké Adjoukrou was more cohesive (sticky) than attiéké Ebrié. By this character (Table 5), it is closer to attiéké Alladjan and is much appreciated by consumers. Its cohesive (sticky) character is appreciated by $70 \%$ of consumers. Attiéké Ebrié was less cohesive and it existed in the Ebrié ethnic group two another types called "Agbodjama" (large grains) and "N'tonié" (with small grains) that grains are more stain remover. About 63\% of consumers appreciated attiéké Ebrié because of its non-sticky nature. Only 37\% of consumers surveyed preferred it cohesive (sticky) texture. Most of Ivorian consumers or other nationalities appreciated the cohesive (sticky) texture of attiéké (traditional and commercial).

Table 5. Preference for cohesive and little cohesive textures according to the types of attiéké

\begin{tabular}{|c|c|c|c|c|c|c|c|c|}
\hline $\begin{array}{l}\text { Types of } \\
\text { attiéké }\end{array}$ & Ebrié & & Adjoukrou & & Alladjan & & Garba & \\
\hline Texture & $\begin{array}{l}\text { Cohesion } \\
\text { between } \\
\text { grains }\end{array}$ & $\begin{array}{l}\text { Little } \\
\text { cohesion } \\
\text { between } \\
\text { grains }\end{array}$ & $\begin{array}{l}\text { Cohesion } \\
\text { between } \\
\text { grains }\end{array}$ & $\begin{array}{l}\text { Little } \\
\text { cohesion } \\
\text { between } \\
\text { grains }\end{array}$ & $\begin{array}{l}\text { Cohesion } \\
\text { between } \\
\text { grains }\end{array}$ & $\begin{array}{l}\text { Little } \\
\text { cohesion } \\
\text { between } \\
\text { grains }\end{array}$ & $\begin{array}{l}\text { Cohesion } \\
\text { between } \\
\text { grains }\end{array}$ & $\begin{array}{l}\text { Little } \\
\text { cohesion } \\
\text { between } \\
\text { grains }\end{array}$ \\
\hline $\begin{array}{l}\text { Preference } \\
(\%)\end{array}$ & 37 & 63 & 70 & 30 & 55 & 45 & 60 & 40 \\
\hline
\end{tabular}

3.1.3 Share of Traditional Attiéké and Garba in Relation to the Consumption of Food Sold on the Abidjan Market

Low-income households ( $r<70,000$ CFA F) preferred consuming attiéké Garba compared to traditional attiéké, rice, cassava, yam and plantain (Figure 3).

Middle-income consumers (70,000 CFA F $<\mathrm{r} \leqslant 200,000$ CFA F) and high income ( $r>200,000$ CFA F) preferred eating traditional attiéké and rice (Figure 4) compared to attiéké Garba, cassava in other forms of preparation, yam and plantain (Figure 4).

The share of consumption of traditional attiéké and commercial attiéké Garba for middle-income consumers $(70,000$ CFA F $<\mathrm{r} \leqslant 200,000$ CFA F) and high income ( $r>200,000$ CFA F) is respectively $23.44 \%$ and $7.33 \%$ while it is respectively $23.89 \%$ and $38.68 \%$ for low-income consumers ( $r<70,000$ CFA F).

\subsubsection{Classification of Quality Descriptors of Different Types of Attiéké by Households}

A list of quality descriptors of attiéké was drawn up among the households surveyed. These descriptors are ranked by importance according to the percentages assigned by the 561 households surveyed. Comparison of percentages showed the importance of taste $(65 \%)$, bright or translucent appearance (35\%), fibers in attiéké $(33 \%)$, color (22\%) and odor (21\%) (Figure 5).

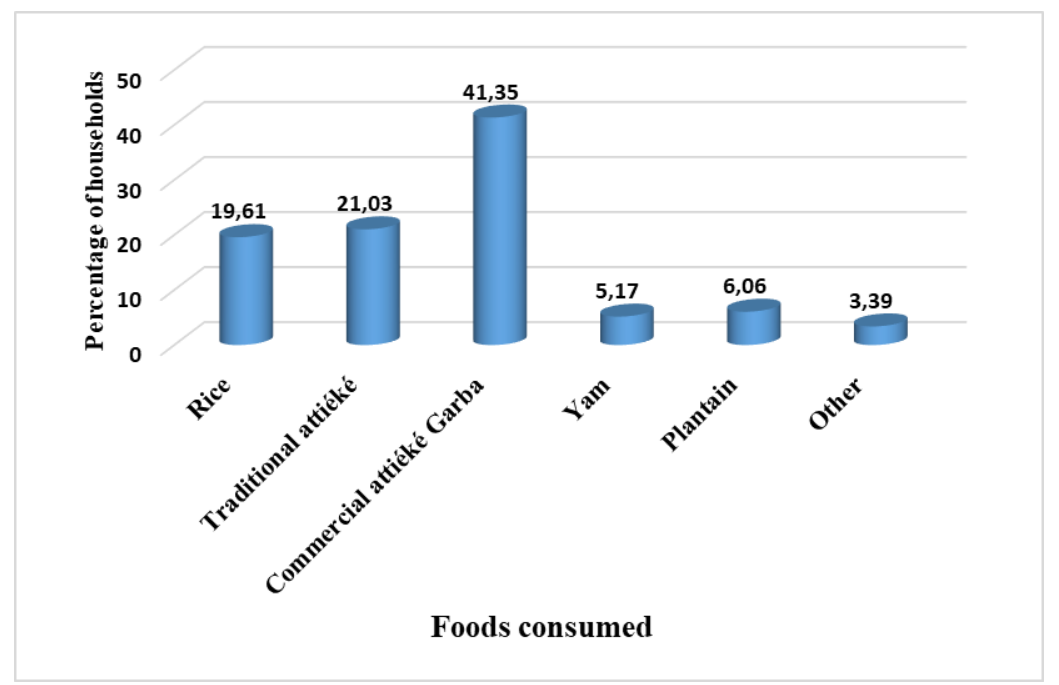

Figure 3. Preference for consumption of traditional attiéké and attiéké garba relative to other foods sold on the market at the level of low-income households 
The 561 households attributed to the taste descriptor, a great importance in the choice of good attiéké. On the other hand, for consumers, translucent or bright and fibrous characters were more important than odor. Color, odor, firmness, well-formed grains and rounded grains came in third position. The characters, cohesiveness between grains, good conservation and grain size, appeared as secondary in the perception of the 561 households Moisture, health, elasticity, well-being and flavor were not important factors for consuming households (Figure 5).

\section{Discussion}

\subsection{Importance and Determinants of Attiéké Consumption}

\subsubsection{Level and Importance of Attiéké Consumption}

The importance and determinants of attiéké consumption were studied in Abidjan, Dabou and Jacqueville. The frequency of regular consumption of attiéké for $99 \%$ of households surveyed showed that attiéké was a very important food for consumers. Indeed, the consumption of this food is increasing throughout the country and remains growing (Kouadio et al., 1991). From cultural value, attiéké has gained social value because it is consumed throughout the country due to its ready-to-eat food and energetic value close to rice (Diop, 1992).

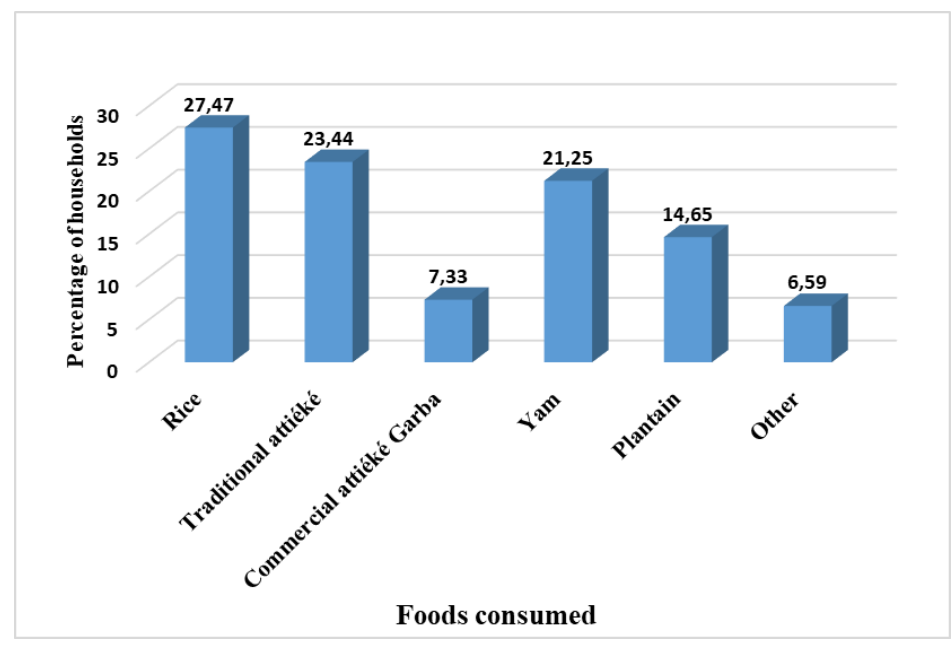

Figure 4. Preference for consumption of traditional attiéké and attiéké Garba compared to other foods sold in the market at the level of high-income and middle-income households

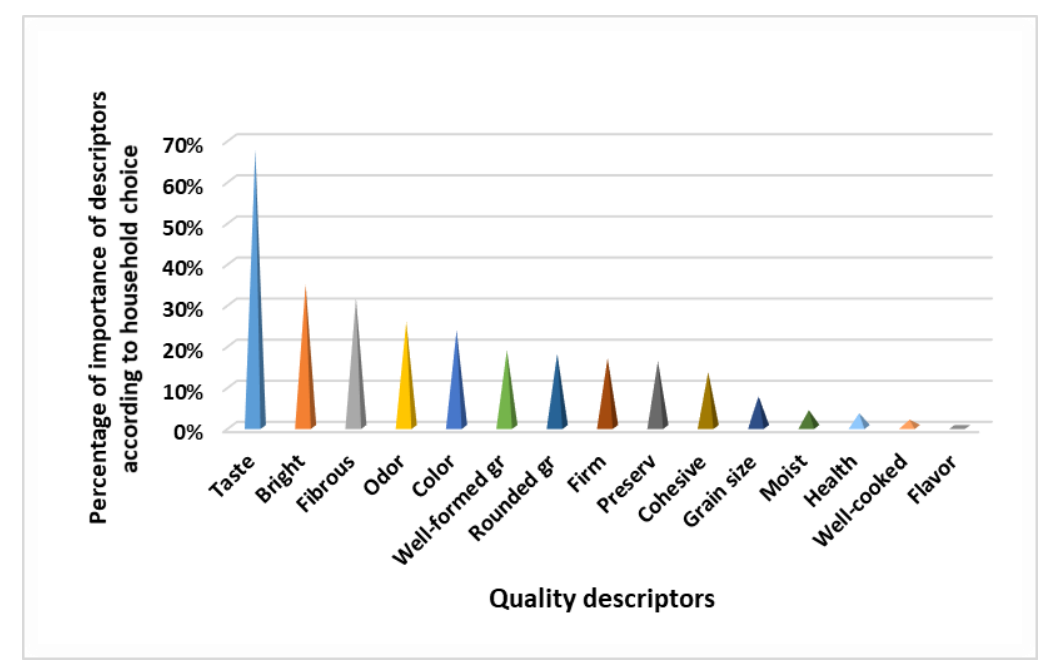

Figure 5. Importance percentage of descriptors of studied attiéké (Adjoukrou, Ebrié, Alladjan and Garba) according to consumers

Well-formed gr: Well-formed Grains, Rounded gr: Rounded grains, Preserv: good food preservation, the bright aspect expresses the translucent character of the attiéké, cohesive: cohesion between grains, health: provides health, Well cooked: well-cooked attiéké 
The frequency of consumption in relation to sex showed that women consume attiéké more than men (twice a day). This could be explained by the fact that women are those who do the market and prepare the food. In addition, they often are in charge of the production and sale of attiéké. Only the attiéké Garba is generally sold and consumed by men.

The frequency of consumption in relation to nationality may be justified by the fact that attiéké is not part of the eating habits of these foreign nationalities. These foreign people cannot always make the difference between traditional and commercial products. The main thing for them is the stamina effect (the starch), the energy produced by the semolina and the tuna fish used. On the other hand, Ivorians prefer consuming more attiéké because a large part of the population is producer community. Then, with the better knowledge of the traditional product, they prefer the traditional attiéké to the attiéké Garba.

It was also noted that the higher the socio-occupational situation, the lower the consumption of traditional attiéké and especially attiéké Garba. This statement also includes the level of education. In fact, traditional attiéké or Garba are essentially carbohydrate (Assanvo et al., 2017) and the knowledge of the side effects of the toxic cassava varieties used for manufacturing traditional attiéké or Garba on health dissuades some consumers. Indeed, this food could lead a possible elevation of blood glucose in case of high consumption. This could have a negative impact on the health of diabetics, obese or overweight individuals (Sievenpiper, Chan, Dworatzek, Freeze, \& Williams, 2018). The risk of toxicity due to a bad elimination of cyanide in attiéké Garba (Assanvo, 2008) could lead to the appearance of endemic goitre and cretinism (Delange, 1994) or paralysis (Banea, Tylleskar, Tylleskar, Gebre-Medhin, \& Rosling, 2000; Banea et al., 2012). The sanitary character of the attiéké Garba can be a source of toxi-infection due to the presence of bacilli (Abe, Assanvo, Sanogo, \& Koffi, 2018) or simply a recontamination caused by a bad handling during sales or packaging (Assanvo, 2008)

The frequency of consumption in relation to the ethnic group showed that Adjoukrou, Ebrié and Alladjan ethnic groups consume more attiéké daily than other ethnic groups and nationalities. This result is justified by the fact that this food constitutes the basis of the diet of these coastal populations of Côte d'Ivoire (Kouadio et al., 1991). According to these authors, the Adjoukrou, Alladjan and Ebrié, lagoon peoples, remain the largest producers and consumers of attiéké and constitute the supply base of the wide Abidjan market. According to UNIDO's Interim Report on the Starchy Food Chain (United Nations Industrial Development Organization [UNIDO], 1990), 100 tons of fresh attiéké were produced daily in 1985, for the city of Abidjan alone, by the artisanal sector. Nowadays, because of the growing demand, other ethnic groups or nationalities that are not originally producers, are quite present on the market. These are Attié, Baoulé, Burkinabé and Togolese, among others who specialized in the production and sale of attiéké Garba. The attiéké Garba originally manufactured by Ebrié producers, is commonly referred to as fast attiéké (or attiéké "speed"). However, new producers not belonging to the traditional producing ethnic groups have become specialists. Traditional attiéké and Garba also have economic value. In Côte d'Ivoire, the ever-increasing demand in cities has made it possible to move from family production to market production (Diop, 1992). Now the product occupies an important place in the local economy with its positive spin-offs along the industry. Urban consumption, particularly in Abidjan, is important because attiéké is a ready-to-eat food (Tano \& Perrault, 1986; Assanvo, Agbo, Brunnchweiler Beez, Monsan, \& Farah, 2018). The popularity of this food has grown in the West African subregion (Burkina Faso, Mali, Ghana, Togo, Benin, Senegal) to the point where it develops in countries like Benin and Ghana, not only networks of production systems but also the appearance of other foods with a similarity to attiéké (Sotomey et al., 2001; Obilie, Tanoh-Debrah, \& Amoa-Awua, 2004). In addition, Essia, Kouebou and Djoulde (2003) present attiéké as a semolina highly appreciated by West and Central African populations. For the rest of the world, attiéké has currently crossed the borders of Europe (France, Belgium, Switzerland), America (Canada and USA) and Asia (Japan, China) through an informal network as in the subregion.

\subsubsection{The Reasons for the Consumption of Attiéké}

The level of income has an impact on the consumption of attiéké. This is because attiéké is cheap and more accessible than other types of foods. The type of attiéké called Garba, being very cheap, is experiencing a marked increase in consumption among people with low incomes, young people and children. However, Tano and Perrault (1986) showed that attiéké will have difficulty replacing imported rice in the dietary habits of mostly urban consumers because of its high cost. According to their study in 1979, attiéké was $62 \%$ more expensive than rice and in 1985, 114\% more expensive. Today, the cheapest cost of attiéké Garba could lead attiéké to overhang rice, given its ever increasing consumption favored by the growing poverty due to the consequences of the war and the high cost of life that Côte d'Ivoire faced. But for this, the quality of the attiéké Garba should be significantly improved to be consumed by all. Other reasons for consumption are to be considered when referring to the percentages of consumption reasons for attiéké. These are, for example, eating 
habits. Cocody, Yopougon and Koumassi communes are major areas of attiéké production and sale. These villages are home to Ebrié villages and some Adjoukrou and Alladjan communities that are set up for on-site production. This justifies the high percentages (35\% and $41 \%$ ) of consumption by eating habit (reason 1) of the communes of Yopougon and Koumassi. This is the case in the villages of Jacqueville (70\%) and Dabou (65\%). In sum, the high frequency of food consumption is very often linked to eating habits. Massamba \& Treche (1995) show that the high frequency of consumption of chikwangue (fermented product of cassava from retting) in the Congo (central plateau), and inhabitants of the Nairi Valley, was due to the fact that the chikwangue is the staple food of these populations.

For reason 2 (Yopougon, 39\%, Koumassi, 35\% and Cocody, 26\%), some consumers prefer traditional attiéké and / or Garba because it satiates more and provides more energy. In these communes, some people consume attiéké for its good taste.

Considering the percentages of reason 3 (Cocody, 46\%, Koumassi, $40 \%$ and Yopougon, 14\%), even though Cocody community contains many high-income people, a segment of the population with a low income lives there too. Also, the presence of "maquis", restaurants, university residences (campus) and schools can justify the high consumption of traditional attiéké and Garba in this area.

\subsubsection{Influence of the Preference and Location of a Type of Attiéké on the Consumption}

The preference and location of a type of attiéké influence the consumption. Attiéké Adjoukrou appears to be the most appreciated by consumers (38\%). The second type of attiéké is the attiéké Ebrié, followed by attiéké Alladjan. This last type of attiéké, in terms of quality, is close to Adjoukrou attiéké but its lesser popularization explains its third rank. Attiéké Garba is less appreciated especially because of its poor quality. It is produced for commercially purpose by new producers who do not always master the production process.

The distribution of consumption of attiéké according to the communes indicated that in Cocody, the consumers surveyed eat both attiéké Ebrié and attiéké Adjoukrou. This can be explained by the presence of Ebrié villages and attiéké Adjoukrou is more sold on the Cocody market for its strong demand in this locality of Abidjan. In Koumassi, attiéké Adjoukrou is also much more appreciated than the Ebrié and Alladjan types. Attiéké Garba seems more popular in Koumassi than in Yopougon and Cocody. A food can be consumed even if not prefer for different reasons (economic, accompaniment, etc). In the villages of Dabou and Jacqueville, the preference is focused on attiéké locally produced. This is due to cultural reason and food habit. The situation is the same in the Ebrié villages

\subsection{Importance of Attiéké Quality Descriptors for Consumers' Households}

4.2.1 Influence of the Assessment of Attiéké Organoleptic Characteristics of and the Type of Consumers on the preference of attiéké

The preference of a type of attiéké is related to the appreciation of the organoleptic characters. Indeed, according to Lenglet (2006), the three factors of sensory acceptability and consumer palatability are: appearance (shape, color) under vision; the flavor (aroma, flavor) related to odor and taste, and the texture (resistance, consistency) of touch. In the case of attiéké, taste, texture, odor, color, and digestion are particularly important characteristics of consumer choice. Two types of consumers stand out: the first group comprises the most warned consumers who are most often the households belonging to different producing ethnic groups, and especially attiéké sellers. The second group is composed of non-warned consumers, often disregarding attiéké. According to the consumers of group 1, the appearance of grains (shape and texture), odor, taste (acid, neutral, sweet, salty) and color are the main criteria for assessing attiéké. The grains should be round, similar to the shape of the fish eggs. They may be sticky or not sticky linked to the preference of the producing ethnic group. In the case of odor, the statement not pleasant means the product is of poor quality, not fresh or not well cooked. The characters of the taste, very little acid, neutral and slightly sweet, are the most sought. The acidic nature is one of the limiting factors in the choice of attiéké although it is a food resulting from a fermentative process. The salt criterion does not matter because salt can be added when needed. Attiéké Alladjan is known for its salty character, seawater is used during the manufacturing process.

More than half of the consumers surveyed prefer attiéké Adjoukrou because it is more cohesive than attiéké Ebrié. This texture is appreciated by easy hand manipulation. Attiéké Ebrié and its variants "Agbodjama" and "N'tonié", (Assanvo, 2008) were originally reserved for ceremonies. Today, with the demand and the grains cohesive character sought by consumers, a more cohesive attiéké variant than traditional attiéké Ebrié has emerged.

Native consumers of traditional attiéké do not appreciate attiéké Garba. However, this attiéké is more and more 
appreciated by a slice of the population living in Côte d'Ivoire. If at the bôginning low or average income justified the consumption of Garba, today this attiéké has entered the diet of the populations (adults, young people, children) living in big cities like Abidjan. It begins to constitute a food habit for these new consumers despite its low quality. At the organoleptic level, attiéké Garba does not meet the standards of traditional producers including the presence of well-made grains, slightly acidic taste, cohesiveness of granules, no wet, elasticity and cream color (Assanvo et al., 2018). The color of Garba is more pronounced because of the large amount of oil added. Hence forth attiéké Garba may be take in account in the food of the populations living in Côte d'Ivoire, even if an improvement of its quality is needed (Assanvo, 2008).

\subsubsection{Importance of Quality Descriptors According to Consumers in the Choice of Attiéké during the Purchase}

For the purchase of attiéké, the taste (acidulated, slightly sweet and sometimes salty) is over other characters. This character is therefore an important quality descriptor. Appearance (translucent or shiny appearance, well-rounded and well-rounded grain characters, presence of fibers or absence of impurities, color), odor and texture of attiéké, also appear to be of importance for consumers whether the percentages are not as high as in the case of taste.

For attiéké Garba, after two to three days, there appears an unpleasant smell (off flavor) consequence of an alteration of taste. This type of attiéké is designed to be consumed preferably within 24 hours after its preparation.

The importance percentage of the smell is not as high, however this descriptor plays an important role in the choice of the product for purchase. Similarly, it seems easier to understand the importance that the consumer attributes to the appearance of attiéké. The view allows the identification of the product, evaluation of freshness, the quality of texture and color. It is therefore essential in the choice of refusal or acceptance of a food (Barrett, Beaulieu, \& Shewfelt, 2010). Thus, the informed Ivorian consumer (producers and sellers) gives great importance to the design of grains in attiéké. For most producers interviewed, the granulation step is very important in the manufacturing process of Ivorian attiéké. The term attiéké is only used when the grains are well formed and rounded. The absence of well-formed grains is reported in the case of "attiéké gari" in Benin (Sotomey et al., 2001) and attiéké in Southwestern Ghana (Obilie et al., 2004). These grains play a role in the firmness (in the mouth) of the product attiéké sought by the consumer.

Regarding the other descriptors (cohesion between grains, grain size, moisture, elasticity, flavor), the lack of knowledge or non-perception of these terms can be at the origin of low percentages of importance during the purchase. These descriptors may not count for the consumer. This hypothesis remains to be verified because according to Monneuse (2003), the organoleptic factors of food are a condition for a food intake. However, the sensory system makes the link between the environment, habits and needs and stimulates food intake according to expressions of preferences or rejections (Eertmans, Baeyens, \& Van den Bergh, 2001; Johnson, 2013).

\section{Conclusion}

At the end of these surveys on consumption, it appears that attiéké is a food consumed by the majority of the surveyed households, all sex and age combined.

The consumption of attiéké Garba is increasing in all social classes. The high frequency of consumption is mainly related to social level and ethnicity. Several reasons gathered in three groups explain the consumption of attiéké: the main reason of consumption is the food habit, staple food or favorite food; the second reason is satiation, good taste and nourishing character. The third reason is the economic nature of attiéké, the low cost, availability, well-made appearance, durability and the "ready to consume" nature of attiéké.

Four major elements explain the reasons for the popularity, the commercial success and the preference of traditional attiéké and attiéké Garba among consumers in Côte d'Ivoire and elsewhere:

- characteristic of food ready to eat;

- fact of being a calorific food, very energetic;

- being an accompaniment that can be associated with different types of dishes (fish, red or white meat, vegetables, sauces);

- organoleptic, hedonic and ideal factors (what we think of the food), intervene directly in the motivation and the act of food consumption.

Among the different types of attiéké, attiéké Adjoukrou is the most appreciated by consumers (38\%), followed by attiéké Ebrié. However, the consumption of attiéké Garba (or attiéké "speed") is growing especially for low-income populations. 
In general, during the purchase of attiéké, the most important descriptor for consumers is the taste. The appearance, smell and aroma of attiéké also play a determining role in the choice of attiéké to buy.

All these organoleptic characteristics identified after the consumer survey will allow standardization of the traditional manufacturing process of attiéké and give it reliable standards of quality. This will be beneficial for improving the quality of the finished product, health and well-being of consumers.

\section{Acknowledgments}

The authors thank the Laboratory of Biochemistry and Food Science, the Institute of Food Science of the Swiss Federal Institute of Technology in Zurich (Switzerland) and the Swiss Centre for Scientific Research in Cote d'Ivoire for their technical and financial support.

\section{References}

Abe, A. M. K., Assanvo, J. B., Sanogo, M., \& Koffi, K. M. (2018). Phenotypic characterization of 52 strains of Bacillus isolated from fresh cassava roots grown in Côte d'Ivoire. International Journal of Biological and Chemical Sciences, 12(5), 2284-2293. https://dx.doi.org/10.4314/ijbcs.v12i5.28

Aboua, F. (1998). Optimum conditions for cooking attiéké. Tropical Science, 38, 220-223.

Anonymous (1998). Recensement général de la population et de l'habitation (RGPH). Abidjan: Institut National de la Statistique. Retrieved from http://www.ins.ci/n/documents/rgph/ivoirien18plus.pdf

Anonymous (2014). Recensement général de la population et de l'habitation (RGPH). Abidjan: Institut National de la Statistique. Retrieved from http://www.ins.ci/n/documents/rgph/ivoirien18plus.pdf.

Assanvo, J. B., Agbo, G. N., Brunnchweiler Beez, J., Monsan, V., \& Farah, Z. (2018). Sensory profiling and hedonic evaluation of Attiéké from Local and Improved Cassava Varieties. Food and Nutrition Sciences, 9 , 1472-1497. https://doi.org/10.4236/fns.2018.912107

Assanvo, J. B., Agbo, G. N., Coulin, P., Monsan, V., Heuberger, C., Kati-Coulibaly, S., \& Farah, Z. (2017). Influence of microbiological and chemical quality of traditional starter made from cassava on attiéké produced from four cassava varieties. Food Control, 78C, 286-296. http://dx.doi.org/10.1016/j.foodcont.2017.02.066

Assanvo, J. B. (2008). Evaluation of traditional Ivorian attiéké qualities: Survey on production and consumption, physicochemical, microbiological and sensory characterization of four cassava varieties (IAC, Bonoua, Olekanga and TMS 4 (2) 1425) (Unpublished doctoral dissertation), University of Cocody, Abidjan, Côte d'Ivoire.

Assanvo, J. B., Agbo, N. G., Behi, Y. E. N., Coulin, P., \& Farah, Z. (2006). Microflora of traditional starter made from cassava for "Attiéké" production. Food Control, 17, 37-41. https://doi.org/10.1016/j.foodcont.2004.08.006

Banea, Mayambu, J. P., Tylleskar, T., Tylleskar, K., Gebre-Medhin, M., \& Rosling, H. (2000). Dietary cyanide from insufficiently processed cassava and growth retardation in children in the DRC. Annals of Tropical Paediatrics, 20, 34-40. https://doi.org/10.1080/02724930092048

Banea, J. P., Nahimana, G., Mandombi, C. Bradbury, J. H., Denton, I. C., \& Kuwa, N. (2012). A Control of konzo in DRC using the wetting method on cassava flour. Food and Chemical Toxicology, 50, 1517-1523. https://doi.org/10.1016/j.fct.2012.02.001

Barrett, D., Beaulieu, J., \& Shewfelt, R. (2010). Color, flavor, texture and nutritional quality of fresh-cut fruits and vegetables: Desirable levels, instrumental and sensory measurement, and effects of processing. Critical Reviews in Food Science and Nutrition, 50(5), 369-389. http://dx.doi.org/10.1080/10408391003626322

Coulin, P., Farah, Z., Assanvo, J., Spillmann H., \& Puhan Z. (2006). Characterisation of microflora of attiéké, a fermented cassava product, during traditional small-scale preparation, International Journal of Food Microbiology, 106, 131-136. https://doi.org/10.1016/j.ijfoodmicro.2005.06.012

Delange, F. (1994). The Disorders Induced by Iodine Deficiency. Thyroid, 4(1), 107-128. https://doi.org/10.1089/thy.1994.4.107

Diop, A. (1992). L'attiéké dans la région d'Abidjan: Analyse économique de la filière traditionnelle à travers quelques types d'organisation (Adjoukrou, Ebrié, Attié...), (Unpublished doctoral dissertation), Université Nationale de Côte d'Ivoire, Centre Ivoirien de Recherches Economiques et Sociales (CIRES), Abidjan, Côte d'Ivoire. 
Dussaix, A. M., \& Grosbras, J. M. (1996). Les sondages: principes et méthodes (2ème édition), Que sais-je $\mathrm{n}^{\circ} 701$, Presses Universitaires de France.

Eertmans, A., Baeyens, F., \& Van den Bergh, O. (2001). Food likes and their relative importance in human eating behavior: review and preliminary suggestions for health promotion. Health Education Research, 16(4), 443-456. https://doi.org/10.1093/her/16.4.443

Essia, N. J-J., Kouebou, C. P., \& Djoulde, D. R. (2003, Novembre). Enrichissement protéique de l'attiéké (semoule à base de manioc): comparaison de deux sources protéiques, Saccharomyces cerevisiae et Voandzeia subterranea (pois de terre), Paper presented at the 2nd Atelier International, Food-based approaches for a healthy nutrition, Ouagadougou. Retrieved from

http://docplayer.fr/74185710-Theme-4-small-scale-industrial-food-production-and-fortification-for-increase d-micro-nutrient-bio-availability.html

Fortin, J., Desmarais, G., Assovie, O., \& Diallo, M. (1998). L'attiéké, couscous de la Côte d'Ivoire, le Monde alimentaire, 2, 22-24.

Gnagne, G-B. A. A., Koffi, E. K. Assanvo, J. B., \& Soro, S. (2016). Influences of freezing and drying of attiéké on its physicochemical and organoleptic characteristics. International Journal of Biological and Chemical Science, 10(2), 808-819. http://dx.doi.org/10.4314/ijbcs.v10i2.29

Heuberger, C. (2005). Cyanide content of cassava and fermented products with focus on attiéké and attiéké "garba", (Doctoral dissertation ETH No 16247), Swiss Federal Institute of Technology, Zurcih. Retrieved from https://doi.org/10.3929/ethz-a-005182128

Johnson, A. W. (2013). Eating beyond metabolic need: how environmental cues influence feeding behavior. Review special issue: Neutral Control of Appetite, Trends in Neuroscience, 36(2), 101-109. https://doi.org/10.1016/j.tins.2013.01.002

Kastner S., Kägi, R., Gnehm N., Assanvo J. B., Farah Z., Lacroix C., \& Meile L. (2006). Molecular characterisation and pectinolytic and cellulolytic potential of Bacillus isolates in the cassava product attiéké. Poster presented at the Trees for Poverty Alleviation, Annual Conference of the Swiss Centre for International Agriculture (ZIL), Zurich, Switzerland. Retrieved from https://www.research-collection.ethz.ch/mapping/eserv/eth:30527/eth-30527-08.pdf

Kastner, S., Tschannen, A., Assanvo, J., Agbo, N. G., Farah, Z., Lacroix, C., \& Meile, L. (2007, Juin). Microbes in cassava fermentation - towards the improvement of attiéké quality and safety. Paper presented at the Proceedings of International workshop: Potential of cassava (Manihot esculenta, Crantz) processing in West Africa, Abidjan, Côte d'Ivoire. Retrieved from http://doczz.fr/doc/1735005/potentialites-a-la-transformation-du-manioc

Kouadio, N. A., Kouakou, K. E., Angbo S. F., \& Mosso, K. (1991). Etude comparative des méthodes traditionnelles de préparation de l'attiéké dans le sud de la Côte d'Ivoire. Cahier Scientifique et Technique, 108, 703-706. Retrieved from http://agris.fao.org/agris-search/search.do?recordID=FR19950104789

Lenglet, F. (2006). Le processus de choix alimentaire et ses déterminants: vers une prise en compte des caractéristiques psychologiques du consommateur. (Doctoral dissertation), Université de Savoie, France. Retrieved from https://hal.archives-ouvertes.fr/tel-01259793/document

Massamba, J., \& Treche, S. (1994). Influence de l'urbanisation sur la consommation de la chikwangue au Congo. In F. Ofori, \& S. K. Hahn (Eds.), Tropical Root Crops in developing economy, proceedings of the ninth symposium of the International society for tropical root crops (pp. 297-303), Accra, Ghana. https://doi.org/10.17660/ActaHortic.1994.380.47

Monneuse, M-O. (2003). La perception d'aliments croquants chez des enfants de 6 à 12 ans: le pain et les pommes. Anthropology of Food, [Online], 1 | September 2003, Online since 01 September 2003, connection on 01 May 2019. Retrieved from http://journals.openedition.org/aof/1269

N'zoré, K. (1985). Transformation du manioc en attiéké: Analyse économique en milieu traditionnel. (Unpublished doctoral dissertation), Institut Agronomique et Vétérinaire, Hassan II Rabat.

Obilie, E. M., Tanoh-Debrah K., \& Amoa-Awua, W. K. (2004). Souring and breakdown of cyanogenic glucosides during the processing of cassava into akyeke, International Journal of Food Microbiology, 93, 115-121. https://doi.org/10.1016/j.ijfoodmicro.2003.11.006

UNIDO (1990). Formation of a strategy of an action plan for the development of the agro-food industry in Côte 
d'Ivoire; starchy die; interim report, August. Retrieved from https://mafiadoc.com/urban-food-consumption-patterns-in-developing-countries_5b69f4ab097c4776628b45 bc.html

Sievenpiper, J. L., Chan, C. B., Dworatzek P. D., Freeze C., \& Williams S. L. (2018). Nutrition, Therapy Diabetes Canada Clinical Practice Guidelines Expert Committee. Canadian Journal of Diabetes, 42, S64-S79. https://doi.org/10.1016/j.jcjd.2017.10.009

Sotomey, M., Ategbo, E.-A., Mitchikpe, E., Gutierrez M.-L., \& Nago, M. C. (2001). L'attiéké au Bénin. Innovations et diffusion de produits alimentaires en Afrique, CERNA, CNEARC, CIRAD, France.

Tano \& Perrault (1986). La commercialisation des vivriers à Abidjan. Rapport préliminaire, CIRES.

Tillé, Y. (2001). La théorie des sondages: Echantillonnage et estimation en populations finies. Cours et exercices corrigés, Dunod, Paris, pp. 296.

\section{Copyrights}

Copyright for this article is retained by the author(s), with first publication rights granted to the journal.

This is an open-access article distributed under the terms and conditions of the Creative Commons Attribution license (http://creativecommons.org/licenses/by/4.0/). 